\title{
Optimization of thermo-mechanical reliability of solder joints in crystalline silicon solar cell assembly
}

\author{
M. T. Zarmai*, N. N. Ekere, C. F. Oduoza and E. H. Amalu \\ School of Engineering, Faculty of Science and Engineering, \\ University of Wolverhampton, WV1 1LY, UK, $\underline{\text { m.t.zarmai@wlv.ac.uk }}$
}

\begin{abstract}
A robust solder joint in crystalline silicon solar cell assembly is necessary to ensure its thermo-mechanical reliability. The solder joint formed using optimal parameter setting accumulates minimal creep strain energy density which leads to longer fatigue life. In this study, thermo-mechanical reliability of solder joint in crystalline silicon solar cell assembly is evaluated using finite element modelling (FEM) and Taguchi method. Geometric models of the crystalline silicon solar cell assembly are built and subjected to accelerated thermal cycling utilizing IEC 61215 standard for photovoltaic panels. In order to obtain the model with minimum accumulated creep strain energy density, the $\mathrm{L}_{9}\left(3^{3}\right)$ orthogonal array was applied to Taguchi design of experiments (DOE) to investigate the effects of IMC thickness $\left(\mathrm{IMC}_{\mathrm{T}}\right)$, solder joint width $\left(\mathrm{SJ}_{\mathrm{W}}\right)$ and solder joint thickness $\left(\mathrm{SJ}_{\mathrm{T}}\right)$ on the thermo-mechanical

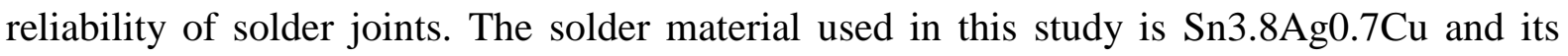
non-linear creep deformation is simulated using Garofalo-Arrhenius creep model. The results obtained indicate that solder joint thickness has the most significant effect on the thermomechanical reliability of solder joints. Analysis of results selected towards thermomechanical reliability improvement shows the design with optimal parameter setting to be: solder joint thickness - $20 \mu \mathrm{m}$, solder joint width $-1000 \mu \mathrm{m}$, and IMC thickness $-2.5 \mu \mathrm{m}$. Furthermore, the optimized model has the least damage in the solder joint and shows a reduction of $47.96 \%$ in accumulated creep strain energy density per cycle compared to the worst case original model. Moreover, the optimized model has 16264 cycles to failure compared with the expected 13688 cycles to failure of a PV module designed to last for 25 years.
\end{abstract}

Keywords: Solar cell assembly, Solder joints, Optimization, Thermo-mechanical reliability, Finite element method, Taguchi method

\section{Introduction}

The dominance of wafer-based crystalline silicon photovoltaic (PV) modules over thin-film modules remains strong despite concerted efforts towards production of the latter. The global production of wafer-based crystalline silicon PV modules in 2013 was $90.956 \%$ of global module production [1]. Wafer-based crystalline silicon PV modules have the advantage of decades of proven technology, higher efficiency than most of their thin-film competitors, decreasing cost of production as well as increasing demand. Though this trend is expected to continue for a long time, certain aspects of the manufacturing technology of wafer-based crystalline silicon PV modules still need to be improved. The manufacturing process of conventional wafer-based crystalline silicon PV modules involves printing silver (Ag) busbar electrode unto the front surface of silicon solar cell wafer. This process is followed by high temperature soldering of highly conductive solder-coated copper ribbon strip on the printed 
Ag busbar while an extended part of the ribbon strip is soldered to the back of a neighbouring cell to form a series connection. The solder joint enables current transfer from the front of one cell to the back of a neighbouring cell. Additionally, the solder joint in the assembly act as mechanical support to hold the ribbon strip to the silicon wafer via Ag busbar. Furthermore, the solder joint function as thermal conduit to dissipate heat away from the silicon wafer. At the present time, lead-free solder alloys such as tin-silver-copper (SAC) alloys are used for the interconnection of solar cells instead of the hazardous lead-based solder alloys which were formerly used.

Moreover, crystalline silicon PV modules are expected to last up to 25 years in field operations. Guyenot et al [2] estimated that for 1.5 thermal cycles per day with a temperature change of about $50{ }^{\circ} \mathrm{C}$, expected life of solder joints for 25 years is 13688 cycles to failure. However, the high temperature soldering of these solar cells induces thermo-mechanical stress in the solder joints thereby diminishing the expected lifespan. In addition, the soldering results in the diffusion of copper $(\mathrm{Cu})$ and tin $(\mathrm{Sn})$ elements to form intermetallic compound (IMC) layers at the solder and copper ribbon interface. Likewise, $\mathrm{Ag}$ and $\mathrm{Sn}$ elements diffuse to form IMC layers at the solder and Ag busbar interface. The IMC layer formed at the interface joint between solder and copper ribbon, consists mainly of $\mathrm{Cu}_{3} \mathrm{Sn}$ and $\mathrm{Cu}_{6} \mathrm{Sn}_{5} \mathrm{IMCs}$ while at the solder and $\mathrm{Ag}$ busbar solder interface joint, the IMC layer consist of $\mathrm{Ag}_{3} \mathrm{Sn}$ intermetallic compounds [3]. In the course of field operations, PV modules undergo thermomechanical fatigue loading due to thermal cycling and differences in the coefficient of thermal expansion (CTE) of the interconnect materials. The result of the thermal effect is further growth of the IMCs in the solder joint which is detrimental to the solder joint fatigue life [4]. In an experimental study, Schmitt et al [3] reported that IMCs decrease the performance and reliability of solder joints in PV modules. Moreover, as the solder joint undergoes isothermal aging, the IMC thickness increases. Also, the fatigue loading creates creep deformation in the solder joint. The deformation is stored internally throughout the volume of solder joint as creep strain energy. Creep strain energy per unit volume of material is referred to as creep strain energy density. As IMC thickness increases, solder joint volume decreases and more creep strain energy density accumulates in the solder joint. Eventually resulting in fatigue failure of the solder joints such that the larger the accumulated creep strain energy density, the shorter the fatigue life. Therefore, minimal accumulated creep strain energy density in the solder joint is desirable as its decrease means the enhancement of thermo-mechanical reliability which leads to longer fatigue life. One of the ways of minimizing accumulated creep strain energy density is through minimizing IMC thickness in the solder joint. Hence, IMC thickness is a factor which affects the thermo-mechanical reliability of solder joint and should be taken into consideration when optimizing the parameter setting of the joint.

Other factors which also need to be considered for optimization are solder joint design parameters particularly solder joint thickness and solder joint width. It is desirable that solder joint width is minimized to reduce shadowing losses because the wider the solder joint, the wider the shadow on the solar cell and the lesser the amount of current generated by the solar cell. Conversely, the solder joint thickness should have adequate capacity to transfer generated current to the desired point. It is desirable that optimal solder joint thickness and width are used such that minimal accumulation of creep strain energy density occurs in the solder joint in order to enable longer fatigue life.

Usually, accelerated thermal cycling (ATC) tests are used to experimentally determine the thermo-mechanical reliability of a package [5]. However, the process consumes time and is costly. A better option is numerical analysis of thermo-mechanical reliability of devices as performed by several researchers such as Ladani [6] and Yang et al [7]. Such numerical 
evaluation enables faster, low-cost and efficient determination of thermo-mechanical reliability of solder joints before the device or product is manufactured. Furthermore, the use of the concept of design of experiment (DOE) facilitates robust design of solder joints thereby enhancing thermo-mechanical reliability of solder interconnects. There are numerous DOE tools in use, yet, Taguchi method is popularly used because it is aimed at improving quality as well as allowing the effects of several factors to be determined simultaneously and efficiently [8]. Application of Taguchi method for DOE in this research enables the selection of the best matching combination of geometric parameters for improving the thermomechanical reliability of solder joints under thermal cycling.

In this study, finite element modelling (FEM) and Taguchi method for DOE are employed to evaluate the thermo-mechanical reliability of solder joints with various sets of parameters and subjected to thermal cycling. The effects of IMC thickness $\left(\mathrm{IMC}_{\mathrm{T}}\right)$, solder joint width $\left(\mathrm{SJ}_{\mathrm{W}}\right)$ and solder joint thickness $\left(\mathrm{SJ}_{\mathrm{T}}\right)$ on the thermo-mechanical reliability are also investigated for optimal parameter setting of the solder joints in crystalline silicon solar cell assembly. The solder joint formed using optimal parameter setting accumulates minimal creep strain energy density which leads to longer fatigue life.

\section{Solar cell assembly and reliability}

The structural design of solar cell assembly used in this study and a brief overview of solder joint reliability are presented in two parts: Structural design of solar cell assembly and solder joint reliability.

\subsection{Structural design of solar cell assembly}

The process of manufacturing conventional wafer-based crystalline silicon solar cell assembly begins with the use of silicon wafer as a base. Unto this base is deposited a layer of emitter material followed by the deposition of a layer of an anti-reflection coating (ARC). The function of the ARC layer is to ensure passage of all light to the silicon crystalline layers while minimizing reflection. Still, a transparent adhesive is deposited on the overlaid coating. Two layers of silver (Ag) in grid form are then printed on the cell's semiconductor material such that the metallization penetrates the ARC layer and makes contact with silicon wafer to form the front metal contact and to collect electric current generated. The printed Ag contacts are fired. Normally, aluminium contacts are also printed at the back surface of the cell material. Depicted in Fig. 1 is a typical schematic of cross-section of a laminated crystalline $\mathrm{Si}$ solar cell assembly. It consists basically of material layers including inter-metallic compounds. It can be observed from the figure that a rear contact material supports silicon wafer. The silicon wafer serves as a semiconductor consisting of a P-type layer at the rear and an N-type layer on the front. Crystalline silicon solar cells are interconnected with other cells in series and parallel to form a PV module of the required voltage and current. Figure 2 shows a schematic of crystalline silicon solar cells interconnected in series with tabbing ribbon. The interconnection materials consist of copper ribbon, solder alloy and Ag busbar which have different coefficient of thermal expansion (CTE). The CTE mismatch induces thermo-mechanical stresses in the solder joint during soldering as well as during service operations resulting in fatigue and eventual failure. Therefore, robust packaging of the PV module is necessary to ensure the solder joint maintains integrity and reliability through subsequent manufacturing processes as well as during service conditions. 


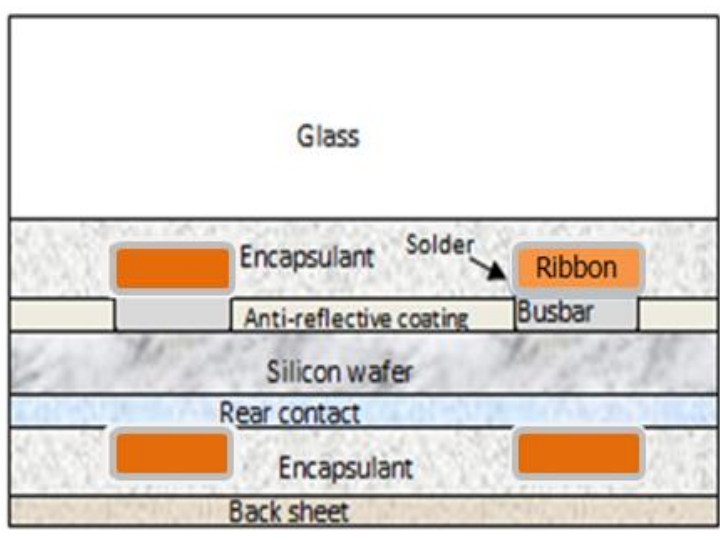

(a)

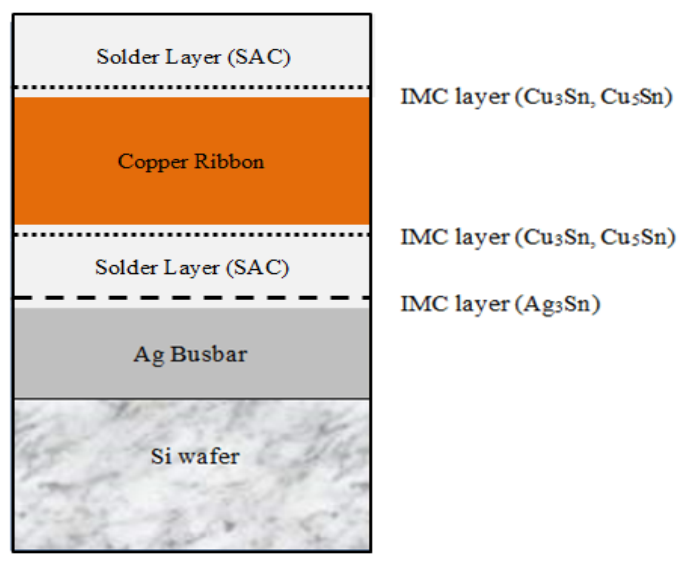

(b)

Fig. 1: Schematic of cross-section of typical crystalline Si solar cell assembly showing: (a) encapsulated solar cell assembly (b) soldered interconnects including IMC layers

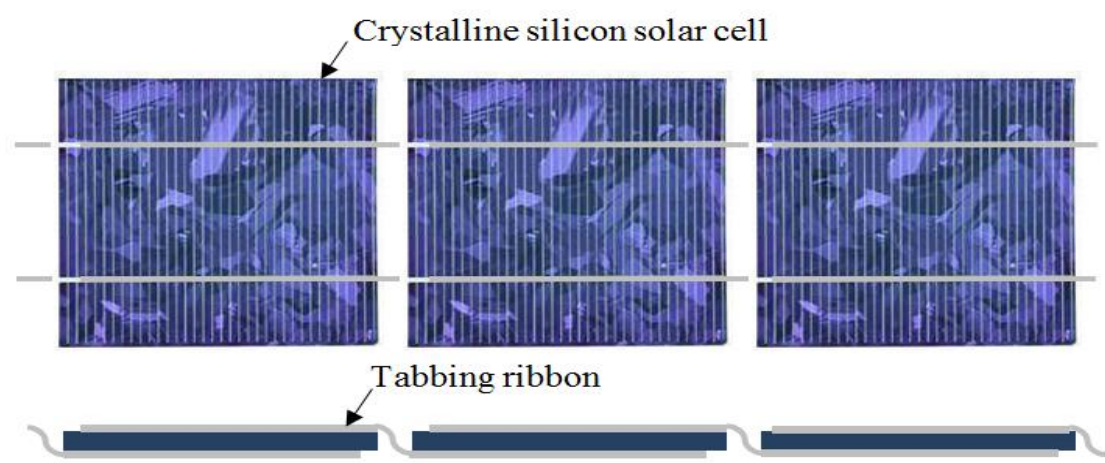

Fig. 2: Crystalline silicon solar cells interconnected in series with tabbing ribbon

\subsection{Solder joint reliability}

Crystalline silicon solar cells are interconnected to each other by soldering highly conductive copper ribbon strips to printed contacts at the front and back surfaces of the cells for current transfer from the front of one cell to the back of a neighbouring cell in a series connection [9] as shown in Fig. 2. As mentioned earlier, solder joints function as electrical connection, mechanical support and thermal conduit which implies that the reliability of solder joints can be affected by a variety of application conditions such as vibration, mechanical shock, thermo-mechanical fatigue, thermal aging and humidity [10]. In separate studies conducted, McCluskey [11] and Cuddalorepatta et al [12] reported that the soldered interconnect joint is the most susceptible part of the solar cell assembly. Besides, in a BP Solar study of PV module field failures, Wohlgemuth [13] reported that cell/interconnect break accounted for $40.7 \%$ of all types of field failures observed. The substantial field failures of interconnects demonstrate their criticality and the need to provide urgent solution to this challenge. This study is focussed on evaluating the critical design parameters of solder joints that impact thermo-mechanical reliability of the joints in crystalline silicon PV modules in order to optimize their designs.

\section{Finite element modelling and simulation}

The study of thermo-mechanical reliability of solder joints in solar cell assembly subjected to thermal cycling using finite element modelling (FEM) is discussed in this section. The 
section consists of three parts: Background and methodology; materials and their properties and results of FEM.

\subsection{Background and Methodology}

This research utilized multi-crystalline silicon solar cell assembly with dimensions $156 \times 156$ $\mathrm{mm}^{2}$ to study induced stress, strain and strain energy in the assembly. The study was carried out using commercial ANSYS academic research finite element package. A Bespoke Work Station computer in the School of Engineering, University of Wolverhampton, UK was used to execute the High Performance Computation (HPC) due to the magnitude of computations involved. Also, in order to lessen modelling time and disc space, quarter symmetry of the geometric models were simulated. Presented in Fig. 3 is a meshed geometric model of the solar cell assembly with interconnected components. The model contains IMC layer at the solder $\mathrm{Cu}$ ribbon interface and also at the solder $\mathrm{Ag}$ bus-bar interface. The IMC layer thickness is assumed to be of the same thickness at each of the interfaces.

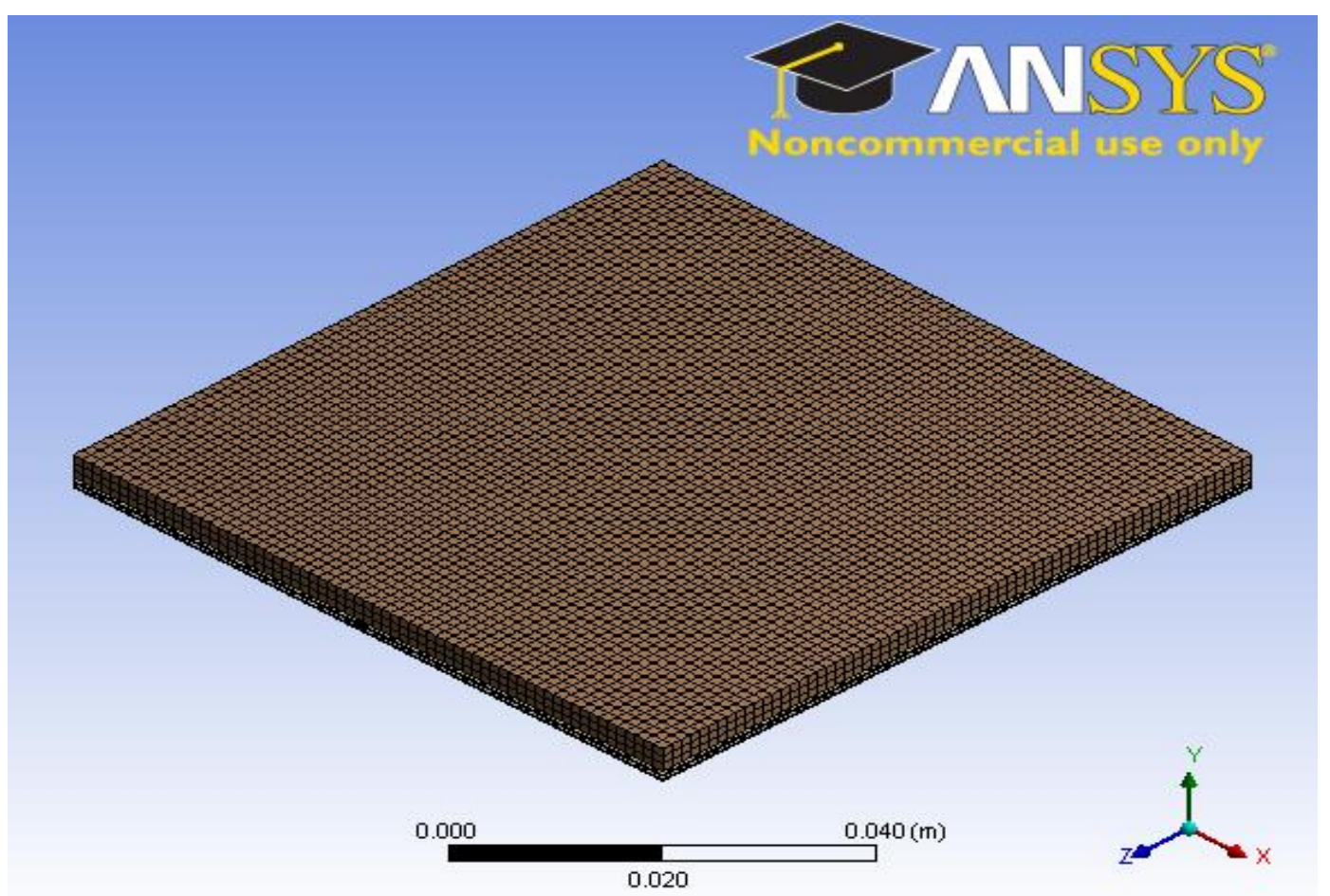

Fig. 3: Meshed crystalline Si solar cell assembly

It is worthy to note that in an experimental study, Schmitt et al [3] reported that the thickness of IMC in a solar cell assembly can grow from about $1 \mu \mathrm{m}$ to about $12 \mu \mathrm{m}$ during thermal cycling depending on the use of either leaded-solder or lead-free solder. Furthermore, in the experimental investigation conducted by Schmitt et al [3] on lead-free SnAg3.5 solder, it was found that IMC layer thickness grew up to $4 \mu \mathrm{m}$. Hence, in this study, IMC layer thickness of $1 \mu \mathrm{m}, 2.5 \mu \mathrm{m}$ and $4 \mu \mathrm{m}$ were used to build geometric models as these values are within the experimental range. The solder joint formed during the interconnection of solar cells is of a particular width and thickness depending on the manufacturer. The solder joint width used ranges from $1000 \mu \mathrm{m}$ to $3000 \mu \mathrm{m}[12,14,15]$. The solder joint width selected for the models in this study are $1000 \mu \mathrm{m}, 1200 \mu \mathrm{m}$ and $1400 \mu \mathrm{m}$. The smaller solder joints widths were selected so as to minimize shadowing losses which will otherwise occur if wider ones are 
selected. Likewise, various solder joint thickness are used by different manufacturers and are usually between the range of $10 \mu \mathrm{m}$ and $40 \mu \mathrm{m}$ [16]. Based on this range of values, this study used $20 \mu \mathrm{m}, 25 \mu \mathrm{m}$ and $30 \mu \mathrm{m}$ as solder joint thickness for the models.

\subsection{Materials and their properties}

The schematic cross-section of solar cell assembly presented in Fig. 1 shows that the solar cell assembly consists of various materials with dissimilar properties. The main interconnection materials are $\mathrm{Sn} 3.8 \mathrm{Ag} 0.7 \mathrm{Cu}$ solder, $\mathrm{Cu}$ ribbon, $\mathrm{Ag}$ bus-bar, IMCs and $\mathrm{Si}$ wafer. These materials and their corresponding properties were assigned to the geometric models built for this study. The mechanical properties of these materials such as Young's modulus, CTE, Poisson ratio and shear modulus are presented in Table 1.

Table 1:

Mechanical properties of materials in solar cell assembly

\begin{tabular}{lccll}
\hline Component & $\begin{array}{l}\text { Young's modulus } \\
\mathrm{E}(\mathrm{GPa})\end{array}$ & $\begin{array}{l}\mathrm{CTE} \\
\alpha\left(10^{-6} /{ }^{\circ} \mathrm{C}\right)\end{array}$ & $\begin{array}{l}\text { Poisson ratio } \\
v\end{array}$ & $\begin{array}{l}\text { Shear modulus } \\
\mathrm{G}(\mathrm{GPa})\end{array}$ \\
\hline Glass [17] & 73.3 & 8.5 & 0.21 & 30.289 \\
\hline Eva encapsulant [18] & 0.011 & 270 & 0.4999 & 0.00367 \\
\hline Cu ribbon [19] & 129 & 17 & 0.34 & 48.134 \\
\hline IMC [19] & 110 & 23 & 0.3 & 42.308 \\
\hline $\begin{array}{l}\text { Solder } \\
\text { (Sn3.8Ag0.7Cu) [19] }\end{array}$ & 43 & 23.2 & 0.3 & 16.538 \\
\hline Ag busbar [20] & 72.4 & 10.4 & 0.37 & 26.423 \\
\hline Si wafer [21] & 130 & 3.5 & 0.22 & 53.279 \\
\hline Al rear contact [20] & 69 & 11.9 & 0.33 & 25.94 \\
\hline Tedlar backsheet [22] & 1.4 & 30 & 0.4 & 0.5 \\
\hline
\end{tabular}

\subsubsection{Constitutive solder model}

Lead-free solder alloy has gained widespread application in electronics interconnection as a response to the recommendation by the National Electronics Manufacturing Initiative (NEMI) [23]. In this study the Sn3.8Ag0.7Cu Solder alloy is used and modelled as viscoplastic material in solar cell assemblies experiencing both rate-dependent and rateindependent inelastic deformation as it undergoes thermo-mechanical loading during accelerated thermal cycling tests as well as in field service. The solder is assumed to exhibit elastic, bilinear kinematic hardening after yield. The elastic and inelastic deformation behaviour of the solder alloy is described by constitutive models. In this study, the GarofaloArrhenius hyperbolic sine creep equation was employed in the finite element analysis (FEA) to simulate the creep behaviour of the $\mathrm{Sn} 3.8 \mathrm{Ag} 0.7 \mathrm{Cu}$ solder joints. This equation in the required format of input for implicit Garofalo-Arrhenius creep model is given by Syed [24]:

$$
\dot{\varepsilon}_{c r}=C_{1}\left[\sinh \left(C_{2} \sigma\right)\right]^{C_{3}} \exp ^{-C_{4} / T}
$$

Where $\dot{\varepsilon}_{c r}$ is creep strain rate, $\mathrm{C}_{1}, \mathrm{C}_{2}, \mathrm{C}_{3}$ and $\mathrm{C}_{4}$ are constants for $\mathrm{Sn} 3.8 \mathrm{Ag} 0.7 \mathrm{Cu}$ solder and $\mathrm{T}$ is the temperature in kelvins. The values of constants $\mathrm{C}_{1}, \mathrm{C}_{2}, \mathrm{C}_{3}$ and $\mathrm{C}_{4}$ for $\mathrm{Sn3}$.8Ag0.7Cu solder are given in the Table 2. 
Table 2:

Generalized Garofalo Creep Constants [24]

\begin{tabular}{lllll}
\hline & \multicolumn{5}{c}{ Constant } \\
\cline { 2 - 5 } & $\mathrm{C}_{1}$ & $\mathrm{C}_{2}$ & $\mathrm{C}_{3}$ & $\mathrm{C}_{4}$ \\
\hline Units & $1 / \mathrm{sec}$ & $1 / \mathrm{Pa}$ & - & $\mathrm{K}$ \\
Value & $2.78 \mathrm{E}+05$ & $2.45 \mathrm{E}-08$ & 6.41 & 6500 \\
\hline
\end{tabular}

236

237

\subsubsection{Fatigue life prediction}

The fatigue life of solder joints subjected to thermal cycling can be predicted using an energy density life prediction model. The model enables the calculation of number of repetitions or cycles to failure. The equation for calculating number of repetitions or cycles to failure using accumulated creep energy density per cycle is given by Syed [24]:

$$
N_{f}=\left(W^{\prime} w_{a c c}\right)^{-1}
$$

Where, $N_{f}=$ Number of repetitions or cycles to failure

$$
\mathrm{W}^{\prime}=\text { Creep energy density for failure and has a value of } 0.0019
$$

$$
w_{\text {acc }}=\text { Accumulated creep energy density per cycle }
$$

In this study, the accumulated creep energy density per cycle is calculated using the volumeaveraged method. The volume-averaged method has been widely used by researchers for the calculation of the accumulated creep energy density per cycle in solder joints [24-26]. The use of volume averaging technique minimizes the effect of mesh sensitivity as well as stress concentration on solder joint fatigue life prediction. The averaged strain energy density obtained through the volume-averaged method is given as $[25,26]$ :

$$
\Delta W_{\text {ave }}=\frac{\sum_{i}^{n} W_{2}^{i} \cdot V_{2}^{i}}{\sum_{i}^{n} V_{2}^{i}}-\frac{\sum_{i}^{n} W_{1}^{i} \cdot V_{1}^{i}}{\sum_{i}^{n} V_{1}^{i}}
$$

Where $W_{2}^{i}, W_{1}^{i}$ is the total accumulated strain energy density in one element at the end point and the starting point of one thermal cycle respectively, $V_{2}^{i}, V_{1}^{i}$ is the volume of element at the end point and start point of one cycle respectively, and $n$ is the number of selected elements to calculate averaged strain energy density.

\subsection{Loads and boundary conditions}

Geometric models of crystalline silicon solar cell assembly were subjected to accelerated thermal cycling utilizing International Electro-technical Commission (IEC) 61215 standard 
for photovoltaic panels to simulate thermal stresses on the materials of the models. The models were subjected to six accelerated thermal cycling in 25 load steps between $-40{ }^{\circ} \mathrm{C}$ to $85{ }^{\circ} \mathrm{C}$. The temperature loading started from $25{ }^{\circ} \mathrm{C}$, ramped up at a rate of $3{ }^{\circ} \mathrm{C} / \mathrm{min}$ to $85{ }^{\circ} \mathrm{C}$, where it had hot dwell for $20 \mathrm{~min}$. It was then ramped down to $-40{ }^{\circ} \mathrm{C}$ at a rate of $6{ }^{\circ} \mathrm{C} / \mathrm{min}$, where it had cold dwell for $20 \mathrm{~min}$. The thermal cycling profile is presented in Fig. 4 and it was used to simulate actual cycling profile used during thermal load test. In the course of such thermal load test, solder joints in crystalline solar cell assembly may crack as a result of thermal fatigue [27].

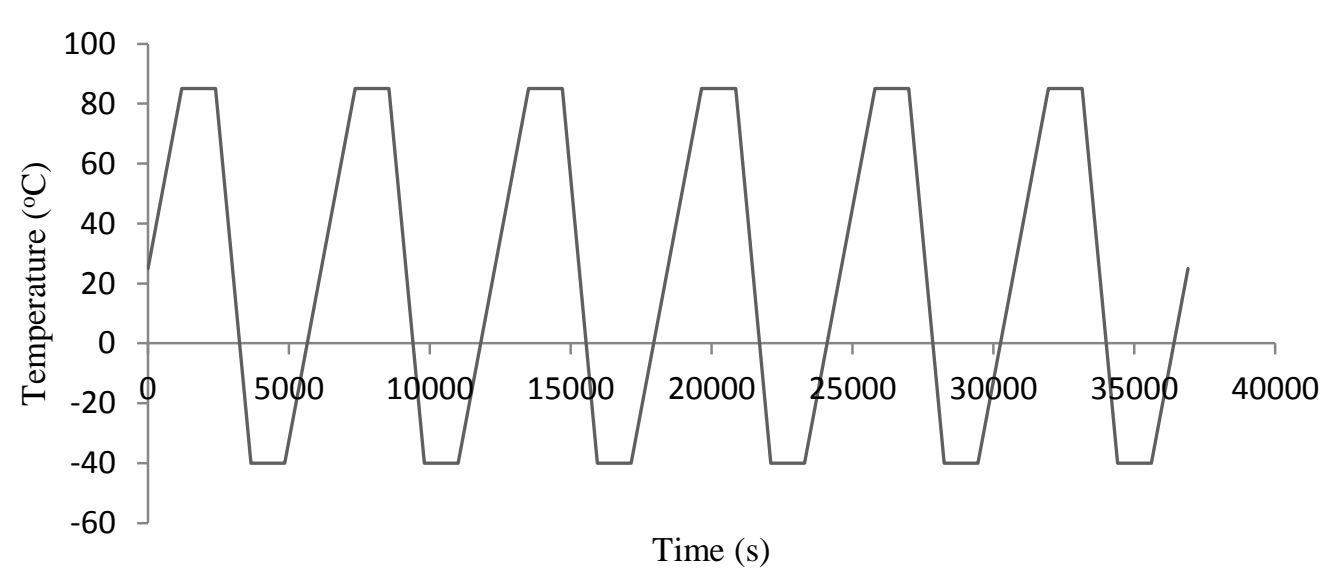

Fig. 4: Plot of temperature profile of thermal load test condition used in the solar cell assembly

\section{Results and discussion}

The optimization of solder joint parameter setting is discussed in this section. The section consists of three parts: DOE using Taguchi method, main experiment as well as analysis and discussion.

\subsection{DOE using Taguchi method}

Design of experiments (DOE) is a tool used by engineers and scientists to design and develop products as well as to develop and improve processes [28]. Taguchi method for DOE is based on quality philosophy aimed at the development of products and processes that are robust to environmental factors and other sources of variability [28, 29]. Robustness in this context is a measure of the ability of the product or process to perform consistently with minimal effect from the uncontrollable noise factors due to operation or manufacturing. The concept of signal-to-noise ratio is used to measure how the performance response varies relative to the desired value under different noise conditions. Furthermore, the use of Taguchi method for DOE substantially reduces product and process development lead time and cost. The benefit of this method is that products and processes are developed which perform better in the field and have higher reliability than those developed using other methods. 
This research utilized Taguchi method for DOE to study the thermo-mechanical reliability of solder joints in solar cell assembly for optimal parameter design of the joints. The following three control factors were chosen: IMC thickness $\left(\mathrm{IMC}_{\mathrm{T}}\right)$, solder joint width $\left(\mathrm{SJ}_{\mathrm{W}}\right)$ and solder joint thickness $\left(\mathrm{SJ}_{\mathrm{T}}\right)$. Also, three DOE variables or levels designated as 1, 2 and 3 which stand for low level, intermediate level and high level respectively are used in this study. These control factors and levels are presented in Table 3.

Table 3:

Control factors and levels

\begin{tabular}{|c|c|c|c|c|}
\hline Control factor & Units & Level 1 & Level 2 & Level 3 \\
\hline A Intermetallic compound thickness $\left(\mathrm{IMC}_{\mathrm{T}}\right)$ & $\mu \mathrm{m}$ & 1 & 2.5 & 4 \\
\hline B Solder joint width $\left(\mathrm{SJ}_{\mathrm{W}}\right)$ & $\mu \mathrm{m}$ & 1000 & 1200 & 1400 \\
\hline $\mathrm{C}$ Solder joint thickness $\left(\mathrm{SJ}_{\mathrm{T}}\right)$ & $\mu \mathrm{m}$ & 20 & 25 & 30 \\
\hline
\end{tabular}

Creep strain energy density is a robust damage indicator of solder joint as it is based on the deformation internally stored throughout the volume of the joint during thermal loading. As a result, accumulated creep strain energy density is used in solder joint life prediction models [24]. In this study, the change in accumulated creep strain energy density $\Delta \omega_{\text {acc, }}$ of the solder joint is chosen as the quality or response factor and used in the Taguchi DOE for optimization. The objective of this optimization is to minimize the accumulated creep strain energy density $\Delta \omega_{\text {acc }}$, in the solder joint as the decrease in $\Delta \omega_{\text {acc }}$ means the enhancement of thermo-mechanical reliability. Minimization of $\Delta \omega_{\text {acc }}$ aims at making the system response as small as possible by obtaining the smaller-the-better signal-to-noise ratio. To achieve this aim, the absolute magnitude of the smaller-the-better signal-to-noise $(\mathrm{S} / \mathrm{N})$ ratio is chosen and is mathematically defined as [5, 29]:

$$
\mathrm{S} / \mathrm{N}=-10 \log \left(\frac{\sum_{i=1}^{n} y_{i}^{2}}{n}\right)
$$

where $y_{i}$ is the $i^{\text {th }}$ value of the quality characteristic and $n$ is the number of values. In this case, the value of the quality characteristic is taken to be $\mathrm{y} \equiv \Delta \omega_{\text {acc. }}$. Besides, since a numerical analysis does not create data variations, then $n=1$. Hence, the equation of the signal-to-noise ratio transforms to:

$\mathrm{S} / \mathrm{N}=-10 \log \left(\Delta \omega_{\mathrm{acc}}\right)^{2}$

The calculation of the chosen $\mathrm{S} / \mathrm{N}$ ratio is through the Taguchi DOE method based on orthogonal arrays. Orthogonal array is an arrangement of numbers in columns and rows in such a way that each column represents a factor while the rows represent levels of the factors [29]. The factors affect the outcome of the process under study. In this study, the $\mathrm{L}_{9}\left(3^{3}\right)$ orthogonal array is applied to Taguchi DOE to investigate the effects of IMC thickness $\left(\mathrm{IMC}_{\mathrm{T}}\right)$, solder joint width $\left(\mathrm{SJ}_{\mathrm{W}}\right)$ and solder joint thickness $\left(\mathrm{SJ}_{\mathrm{T}}\right)$ on the thermo-mechanical reliability of solder joints. Presented in Table 4 is a table of Taguchi DOE (Orthogonal array $\mathrm{L}_{9}$ ) showing nine models and their respective solder joint parameter level. ANSYS DesignModeller was used to build the geometric model of each designed model using their respective parameter setting. 
To obtain the optimal parameter setting of solder joint in solar cell assembly, a main experiment must be implemented. The implementation of the main experiment commences with setting the parameter for each experimental run. Thus, each design of the solder joint is assigned its respective parameter setting as shown in Table 4. The geometric models of the solar cell assembly containing the solder joint are subsequently built with the appropriate parameter setting.

Table 4:

Table of Taguchi DOE (Orthogonal array $\mathrm{L}_{9}$ )

\begin{tabular}{ccccc}
\hline $\begin{array}{c}\text { Model } \\
\text { number }\end{array}$ & \multicolumn{3}{c}{ Factor and level } & \multirow{2}{*}{$\begin{array}{c}\text { Parameter } \\
\text { setting }\end{array}$} \\
\cline { 2 - 4 } & $\mathrm{A}$ & $\mathrm{B}$ & $\mathrm{C}$ & \\
\hline 1 & $1_{(1)}$ & $1_{(1000)}$ & $1_{(20)}$ & A1B1C1 \\
2 & $1_{(1)}$ & $2_{(1200)}$ & $2_{(25)}$ & A1B2C2 \\
3 & $1_{(1)}$ & $3_{(1400)}$ & $3_{(30)}$ & A1B3C3 \\
4 & $2_{(2.5)}$ & $1_{(1000)}$ & $2_{(25)}$ & A2B1C2 \\
5 & $2_{(2.5)}$ & $2_{(1200)}$ & $3_{(30)}$ & A2B2C3 \\
6 & $2_{(2.5)}$ & $3_{(1400)}$ & $1_{(20)}$ & A2B3C1 \\
7 & $3_{(4)}$ & $1_{(1000)}$ & $3_{(30)}$ & A3B1C3 \\
8 & $3_{(4)}$ & $2_{(1200)}$ & $1_{(20)}$ & A3B2C1 \\
9 & $3_{(4)}$ & $3_{(1400)}$ & $2_{(25)}$ & A3B3C2 \\
\hline
\end{tabular}

\subsection{Results of FEM}

Solder interconnect in the solar cell assembly is the critical constituent for consideration of thermo-mechanical reliability of the assembly. Therefore, optimizing the geometry parameters of solder joint is key to enhancing the thermo-mechanical reliability of the solder interconnects. Accordingly, the response of solder joint to thermal cycling is required to provide an insight to solder behaviour. Thus simulation results showing stress, creep strain and strain energy provide useful information on the behaviour of solder joints. In this study, nine original geometric models were built and simulated using ANSYS academic research finite element package. Presented in Fig. 5 are simulation results of damage distribution of solder joint in solar cell assembly for one of the models. The figure shows equivalent stress, equivalent creep strain and strain energy in the solder joint. The maximum damage distribution is at the right side edge, towards the right side edge and at the mid-section of the solder joint for stress, creep strain and strain energy respectively. This indicates that crack initiation and propagation is most likely to occur at the mid-section of the solder joint and will eventually lead to fatigue failure at that preferential failure site. A close observation of Fig. 5(b) reveals that the maximum creep strain damage is located at the lower side of the solder joint adjacent to silver ( $\mathrm{Ag}$ ) bus-bar which is at a similar location to a cracked solder joint in crystalline solar cell assembly shown in Fig. 6. 
A: Static Structural

Equivalent Stress 2

Type: Equivalent (von-Mises) Stress

Unit: $\mathrm{Pa}$

Time: 36900

$08 / 12 / 201511: 44$

\subsection{3e6 Max}

$7.0993 \mathrm{e} 6$

$6.7474 \mathrm{e} 6$

$6.3954 \mathrm{e} 6$

$6.0435 \mathrm{e} 6$

$5.6916 \mathrm{e} 6$

$5.3396 \mathrm{e} 6$

$4.9877 \mathrm{e} 6$

4.6357 e6

4.2838e6 Min

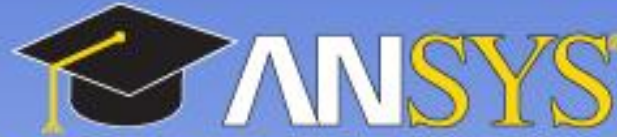

Noncommercial use only

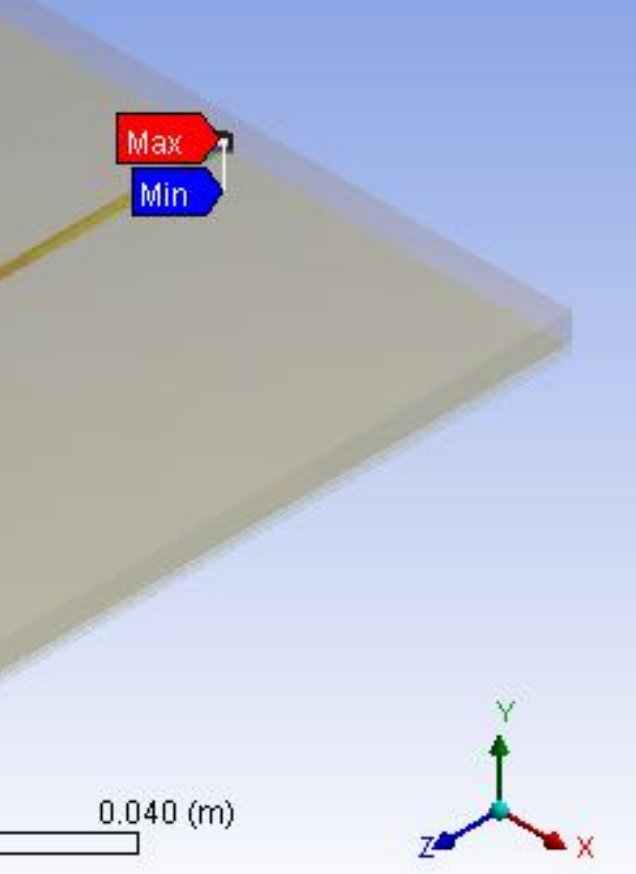


A: Static Structural

Equivalent Creep Strain 2

Type: Equivalent Creep Strain

Unit: mim

Time: 36900

$08 / 12 / 201511: 46$

\begin{tabular}{|l}
$\mathbf{0 . 0 0 0 4 4 8 4}$ Max \\
0.00041191 \\
0.00037542 \\
0.00033893 \\
0.00030244 \\
0.00026596 \\
0.00022947 \\
0.00019298 \\
0.00015649 \\
$\mathbf{0 . 0 0 0 1 2}$ Min
\end{tabular}

A: Static Structural

Strain Energy 2

Type: Strain Energy

Unit: J

Time: 36900

$08 / 12 / 201511: 47$

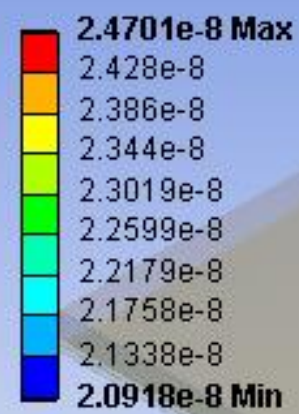

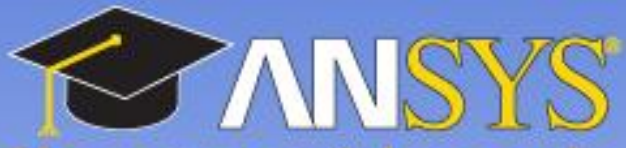

Noncommercial use only

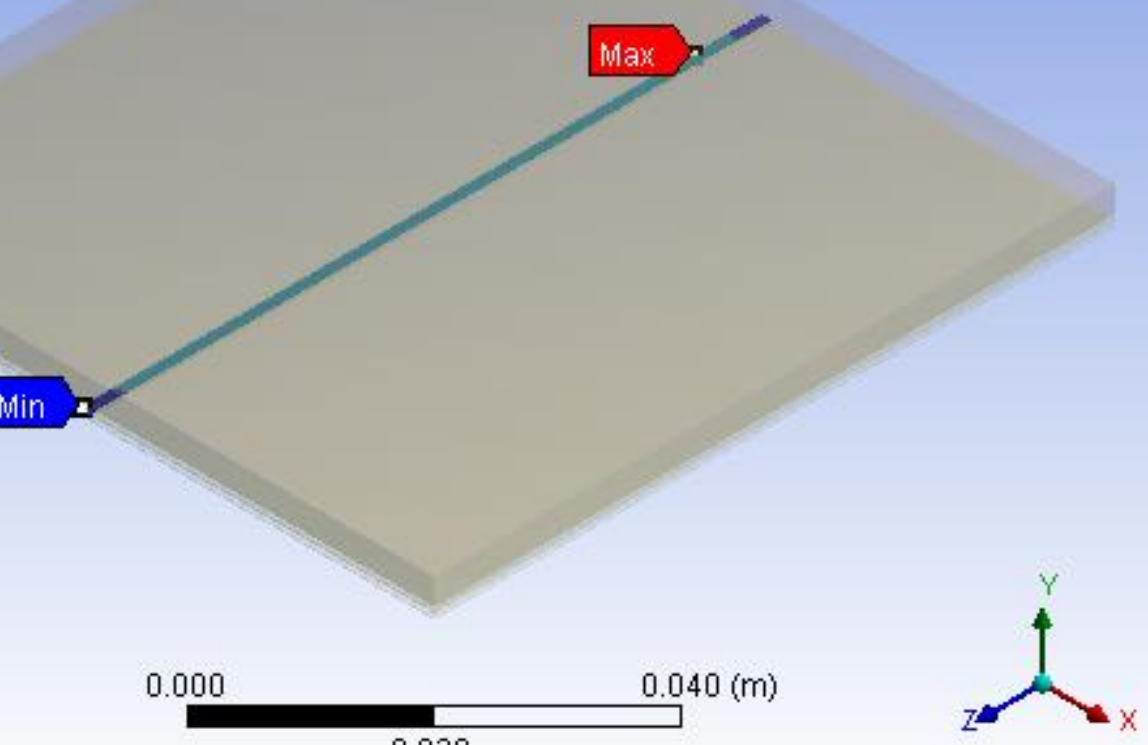

0.020 (b)

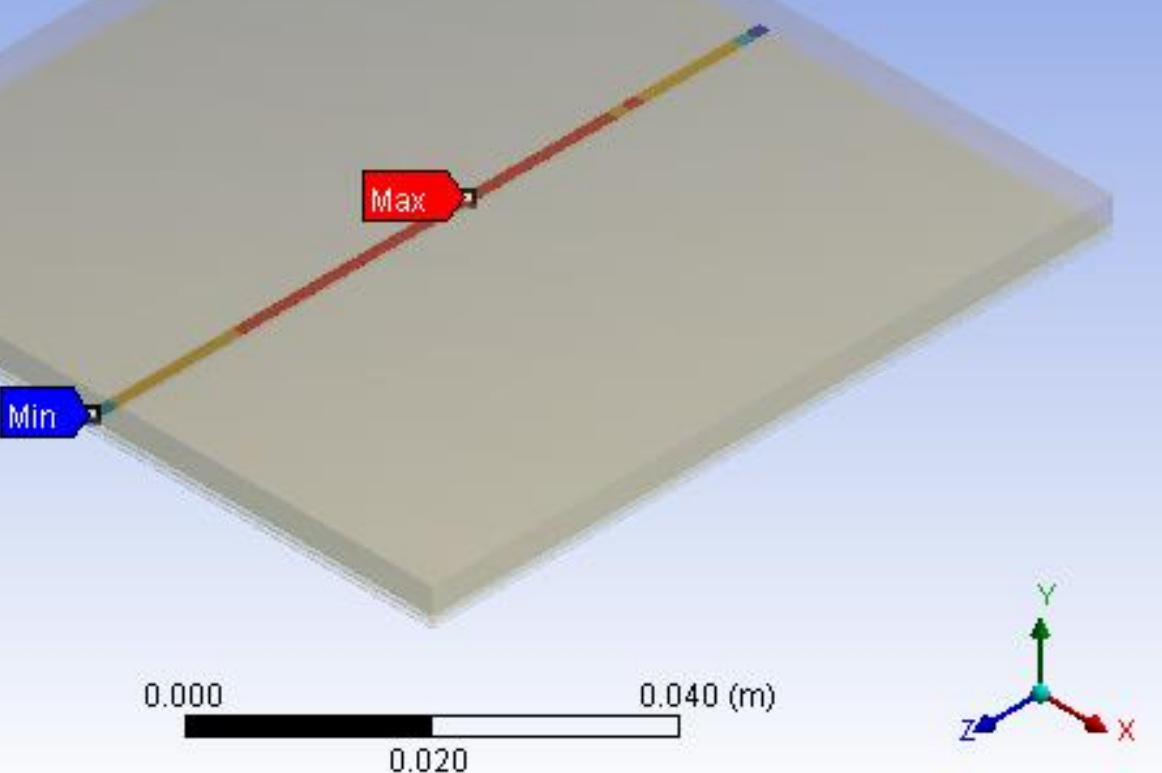


(c)

Fig. 5: Damage distribution in solder joint of the solar cell assembly showing:

(a) Equivalent stress (b) Equivalent creep strain (c) Strain energy

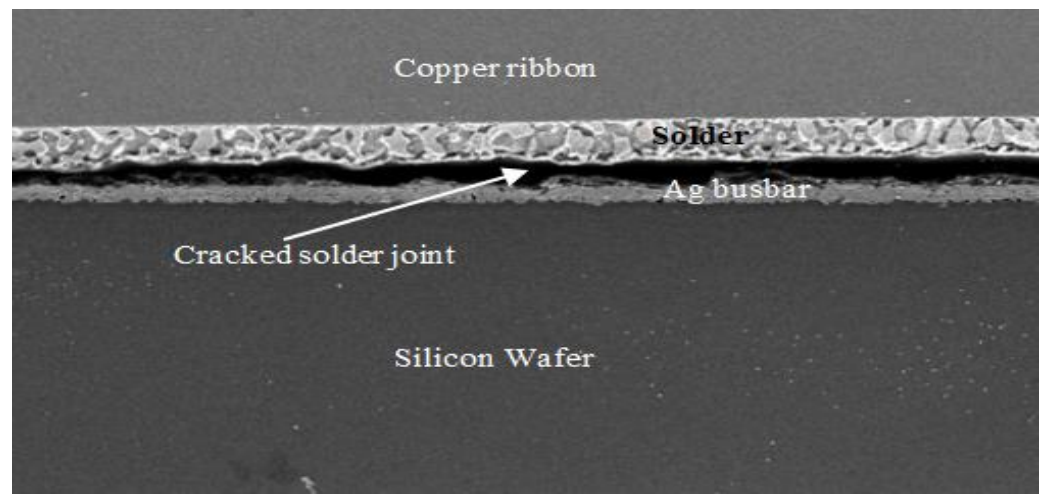

Fig. 6: Cracked solder joint in crystalline solar cell assembly [27]

The plot of accumulated change in creep strain energy density against model number is presented in Fig. 7. It can be observed from Fig. 7 that model number 2 has the largest accumulated change in creep strain energy density $\left(\Delta \omega_{\text {acc }}\right)$ compared to all the other models. This implies that the solder joint in model number 2 is the most susceptible to failure compared to the others. Therefore, model number 2 has the most critical solder joint and hence, is the worst original design compared to the other models.

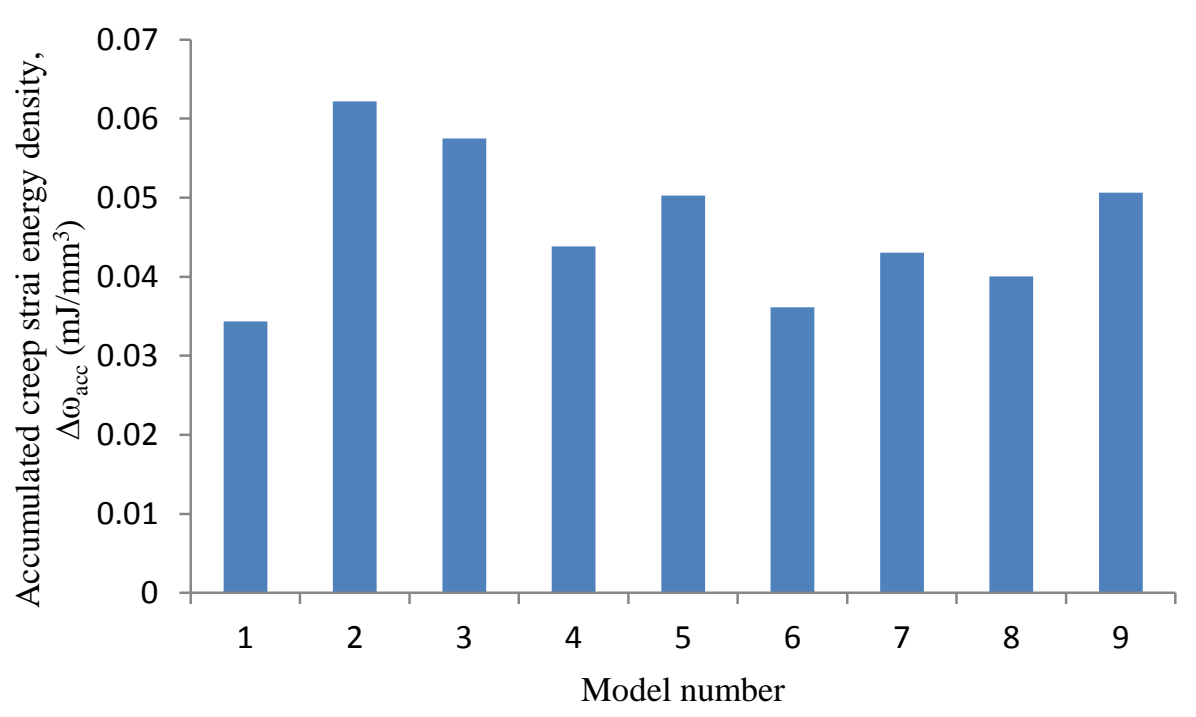

Fig. 7: Plot of accumulated creep strain energy density against model number 
391

392

393

394

Table 5:

Experimental results and $\mathrm{S} / \mathrm{N}$ ratio

\begin{tabular}{ccccccc}
\hline Model & \multicolumn{3}{c}{ Factor and level } & & Quality/Response & S/N ratio \\
\cline { 2 - 4 } & A & B & C & & $\Delta \omega_{\text {acc }}\left(\mathrm{mJ} / \mathrm{mm}^{3}\right)$ & \\
\hline 1 & 1 & 1 & 1 & & 0.03436 & 29.28 \\
2 & 1 & 2 & 2 & & 0.06218 & 24.13 \\
3 & 1 & 3 & 3 & & 0.05750 & 24.81 \\
4 & 2 & 1 & 2 & & 0.04384 & 27.16 \\
5 & 2 & 2 & 3 & & 0.05028 & 25.97 \\
6 & 2 & 3 & 1 & & 0.03613 & 28.84 \\
7 & 3 & 1 & 3 & & 0.04303 & 27.32 \\
8 & 3 & 2 & 1 & & 0.04002 & 27.95 \\
9 & 3 & 3 & 2 & & 0.05061 & 25.92 \\
Average & & & & & $\mathbf{2 6 . 8 2}$ \\
\hline
\end{tabular}

The geometric models were simulated and accumulated creep strain energy density determined from simulation results for each design. The predicted results as well as the computed $\mathrm{S} / \mathrm{N}$ ratio for each design are presented in Table 5.
395

396

397

398

399

400

401

402

403

404

405

406

407

$408 \quad \overline{j_{i}}=\left.\frac{1}{n} \sum_{j_{i}=1}^{n} j_{i}\right|_{\forall j, i}$

.

\subsection{Analysis and discussion}

In this analysis, minimization of the response is desired for accumulated creep strain energy density, $\Delta \omega_{\text {acc }}$ in the solder joint. The averaged effect response for $\mathrm{S} / \mathrm{N}$ ratio of each factor was investigated to determine the contributions of IMC thickness, solder joint width and solder joint thickness on the solder joint thermo-mechanical reliability. Minitab 17 statistical software was used to carry out analysis of variance (ANOVA) on the data presented in Table 5. The main effect plots from ANOVA are shown in Fig. 8 and consist of the plot for IMC thickness, solder joint width and solder joint thickness. Also, presented in Table 6 is the S/N response and rank for the three factors.

The means of $\mathrm{S} / \mathrm{N}$ ratio presented in Table 6 and plotted in Fig. 8 are obtained using the data in Table 5 and applying Eq. 6 for each factor.

409 Where $j$ may be designated as A, B or C represent factor and $i$ stand for values 1,2 or 3 410 represent the level. The symbols $\bar{j}_{i}$ and $n$ are the mean of $\mathrm{S} / \mathrm{N}$ ratio and the number of level in 411 the experiment respectively. The sign $\left.\right|_{\forall j, i}$ denotes that Eq. 6 is evaluated at $j$ and $i$ values.

412 These means represent the factor average effects at each level. Furthermore, with reference to 413 Table 6, the effect of a factor $\left(E_{j}\right)$ is the observed range in its level. It can be represented as: 
414

$E_{j}=F_{j \max }-\left.F_{j \min }\right|_{\forall i}$

415 Where $E_{j}$, is effect of factor $j$ and $F_{j m a x}$ and $F_{j m i n}$, are maximum and minimum value of factor 416

417

418

419

420

421

422

423

424

425

426

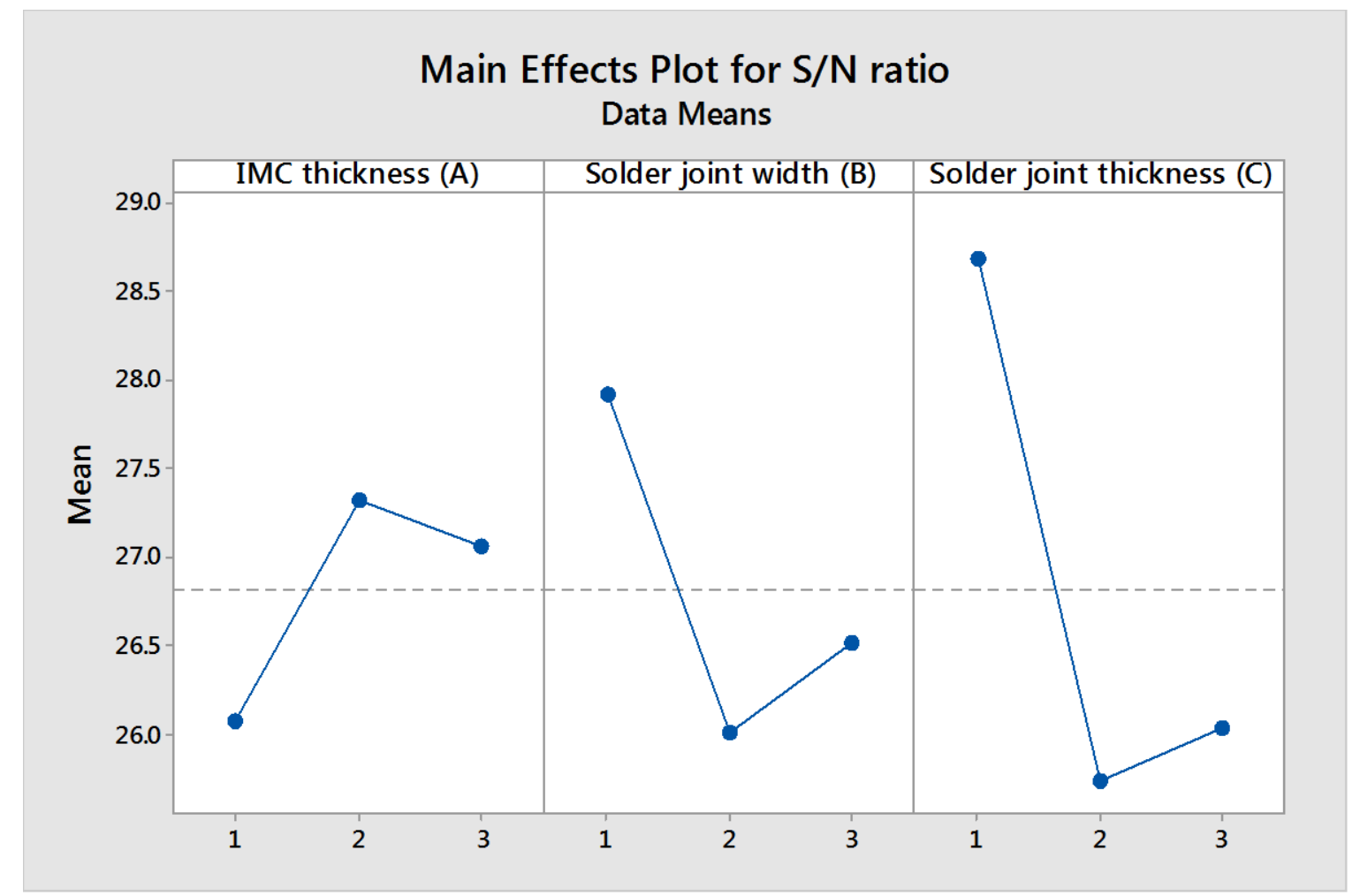

428

Fig. 8: Main effect plot of IMC thickness, solder joint width and solder joint thickness 
Table 6:

$\mathrm{S} / \mathrm{N}$ response and rank

431

\begin{tabular}{lccc}
\hline & \multicolumn{3}{c}{ Factor and level } \\
\cline { 2 - 4 } & $\mathrm{A}$ & $\mathrm{B}$ & $\mathrm{C}$ \\
\hline Level 1 & 26.07 & 27.92 & 28.69 \\
Level 2 & 27.32 & 26.02 & 25.74 \\
Level 3 & 27.06 & 26.52 & 26.03 \\
Effect & 1.25 & 1.90 & 2.95 \\
Rank & 3 & 2 & 1 \\
\hline
\end{tabular}

432 Results from Fig. 8 and Table 6 indicate that the most significant parameter for the thermo-

433 mechanical reliability of solder joint is Factor C (solder joint thickness) as it has the largest 434 effect, hence is ranked $1^{\text {st }}$. Factor A (IMC thickness) is the least significant as it has the least 435 effect, hence ranked $3^{\text {rd }}$. Factor B (solder joint width) has the second largest effect as it is 436 ranked $2^{\text {nd }}$. Furthermore, from Table 6 , the optimal parameter setting based on maximum 437 values is deduced to be A2B1C1 which reveal that the solder joint should have an IMC 438 thickness of $2.5 \mu \mathrm{m}$, width of $1000 \mu \mathrm{m}$ and thickness of $20 \mu \mathrm{m}$.

439 A geometric model of solar cell assembly containing solder joint with the optimal parameters 440 was built and simulated in order to provide results for confirmation and comparison with 441 worst original design (Model 2). Accumulated creep strain energy density was computed 442 from the simulation results of the optimal design and $\mathrm{S} / \mathrm{N}$ ratio was computed as well. 443 Presented in Fig. 9 is comparison of accumulated creep strain energy density of worst 444 original design and optimal design. It can be observed from Fig. 9 that accumulated creep 445 strain energy density in solder joint of worst original design is higher than that of optimal 446 design. This implies that the optimal design makes the solder joint more robust than the worst 447 original design. Comparison of the accumulated creep strain energy density, $\Delta \omega_{\text {acc }}$ and the $448 \mathrm{~S} / \mathrm{N}$ ratio of the worst original design and the optimal design are presented in Table 7 . It can 449 be observed from Table 7 that the optimal design has the smallest accumulated creep strain 450 energy density, $\Delta \omega_{\text {acc }}$ compared to all the other original designs. Furthermore, the optimal 451 design reduces the $\Delta \omega_{\text {acc }}$ by $47.96 \%$ compared to that of the worst original design thereby 452 improving the thermo-mechanical reliability of the solder joints in crystalline silicon solar 453 cell assembly. 


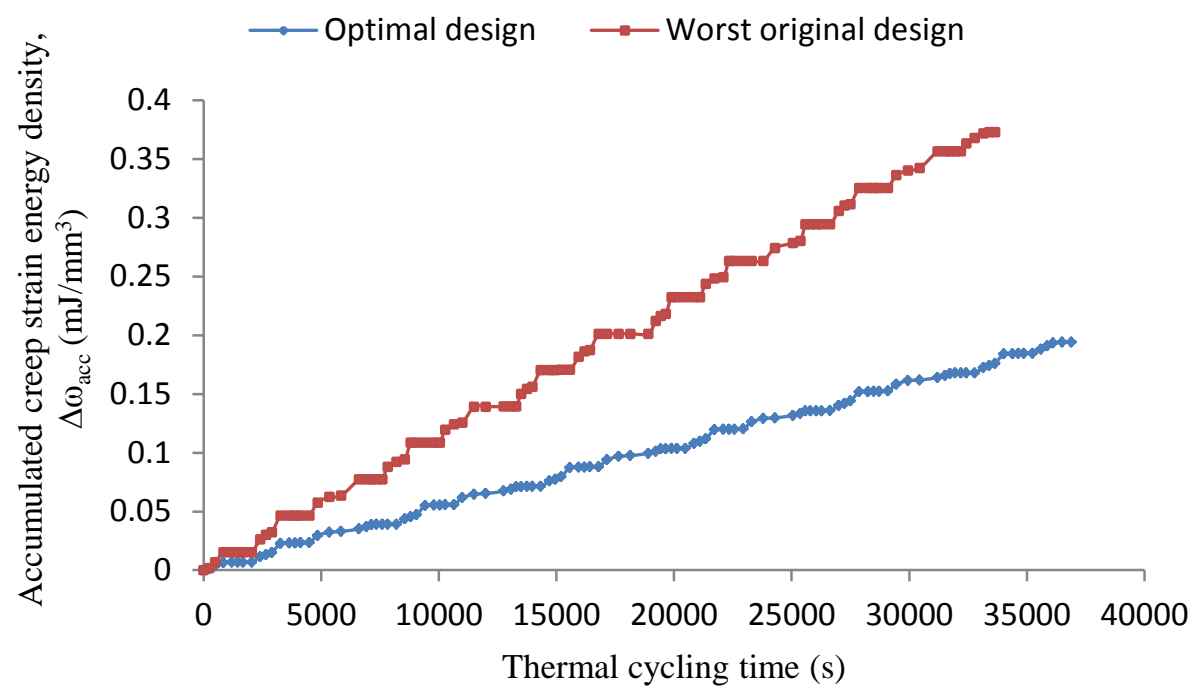

455
Fig. 9: Comparison between accumulated creep strain energy density of original design and optimal design

Table 7:

Comparison of $\Delta \omega_{\mathrm{acc}}$ in worst original and optimal designs

\begin{tabular}{|c|c|c|c|c|c|}
\hline & \multicolumn{3}{|c|}{ Factors and level } & \multirow{2}{*}{$\begin{array}{c}\Delta \omega_{\mathrm{acc}} \\
\left(\mathrm{mJ} / \mathrm{mm}^{3}\right)\end{array}$} & \multirow{2}{*}{$\mathrm{S} / \mathrm{N}$ ratio } \\
\hline & $\mathrm{A}$ & $\mathrm{B}$ & $\mathrm{C}$ & & \\
\hline Worst original design & 1 & 2 & 2 & 0.06218 & 24.13 \\
\hline Optimal design & 2 & 1 & 1 & 0.03236 & 29.80 \\
\hline Reduction & & & & $47.96 \%$ & \\
\hline
\end{tabular}

Furthermore, Eq. 2 was used to compute fatigue life of the solder joints in worst original design as well as in optimal design and the results are shown in Fig. 10. In addition, the expected life of PV modules which is 13688 cycles to failure (25 years) as discussed in section 1 is included in Fig. 10. Besides, in an experimental study, Kumar and Sarkar [30] tested $20 \mathrm{PV}$ modules for stress failure and obtained the least survival life to be 21 years (11497 cycles to failure). This experimental test life is also presented in Fig. 10. 


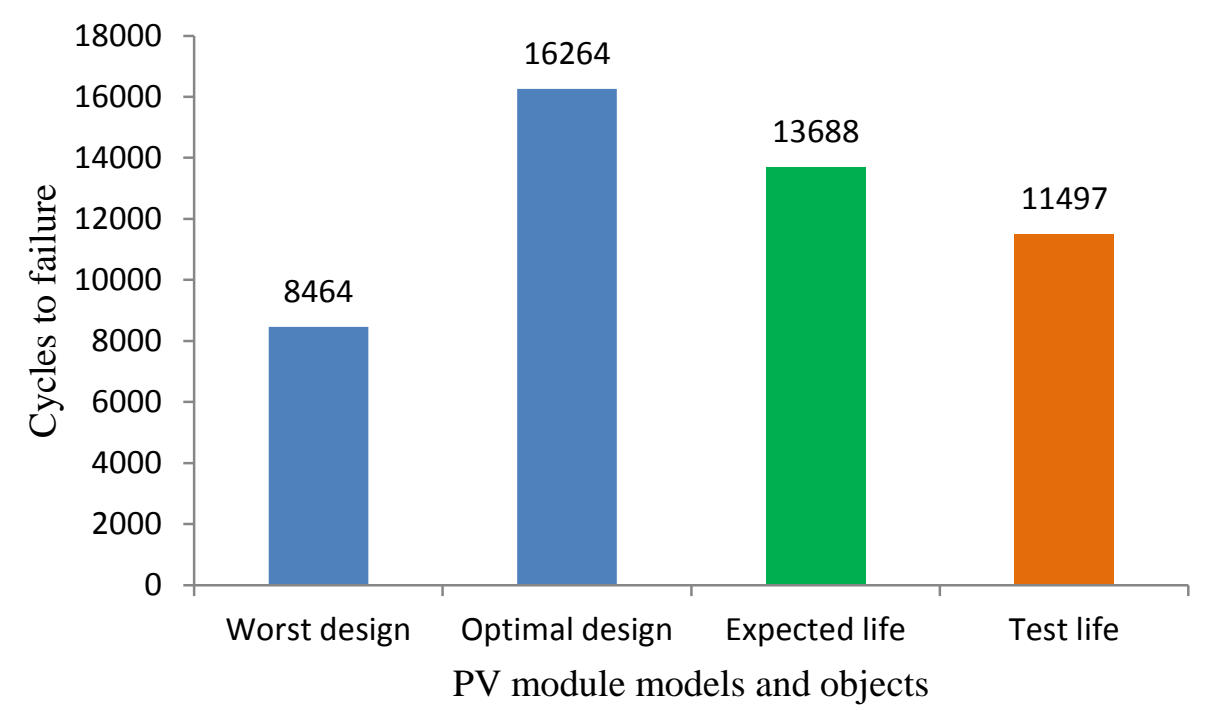

Fig. 10: Predicted cycles to failure of solder joint models compared with expected and test values

It can be observed from Fig. 10 that the predicted solder joint fatigue life of the optimal design is almost double that of the worst original design and higher than the expected life of PV modules. This implies that the solder joint of the optimal design has topmost thermomechanical reliability which is very desirable for the PV modules.

\section{Conclusions}

An investigation of the thermo-mechanical reliability of solder joints in crystalline silicon solar cell assembly using finite element modelling (FEM) and Taguchi method for DOE is reported in this paper. The investigation aims to study the effect of intermetallic compound (IMC) thickness, solder joint width and solder joint thickness on the thermo-mechanical reliability of $\mathrm{Sn3} .8 \mathrm{Ag} 0.7 \mathrm{Cu}$ solder joint with various sets of parameters and subjected to thermal cycling. The focus of this investigation is to minimize accumulated change in creep strain energy density and optimize the parameter setting of solder joint towards the enhancement of thermo-mechanical reliability of the joint.

The results of simulation carried out reveal that the maximum damage distribution is at the mid-section of the solder joint for stress, creep strain and strain energy. The maximum creep strain damage is located at the lower side of the solder joint adjacent to silver (Ag) busbar. This indicates that crack initiation and propagation is most likely to occur at the mid-section of the solder joint and will eventually lead to fatigue failure at that preferential failure site.

Furthermore, the outcomes of this investigation show that the magnitude of accumulated change in creep strain energy density depends on the parameter setting of solder joint. Comparison of the main effects of IMC thickness, solder joint width and solder joint thickness on the thermo-mechanical reliability of the solder joint indicates that solder joint thickness has the most significant effect.

The analysis of parameters selected towards thermo-mechanical reliability improvement of solder joint produced an optimal parameter setting which will make the joint robust. The 
optimal parameter setting for the solder joint is that the solder joint thickness is $20 \mu \mathrm{m}$, solder joint width is $1000 \mu \mathrm{m}$ and IMC thickness is $2.5 \mu \mathrm{m}$. Also, the optimal parameter setting improves the performance of the solder joint by $47.96 \%$ compared to the worst case original parameter setting. Interestingly, the optimized model is predicted to have 16264 cycles to failure which is higher than the expected 13688 cycles to failure of a PV module designed to last for 25 years.

Based on these findings, the authors recommend that manufacturers of wafer-based crystalline silicon photovoltaic modules use this study to analyse and optimize their designs in order to enhance the thermo-mechanical reliability of solder joints.

\section{Acknowledgements}

The authors acknowledge funding provided by the Petroleum Technology Development Fund (PTDF), Nigeria used in carrying out this study.

\section{References}

[1] Burger B, Kiefer K, Kost C, Nold S, Phillips S, Preu R, et al. Photovoltaic Report, Fraunhofer Institute for Solar Energy Systems ISE, Freiburg, Germany, 2014; 1-42.

[2] Guyenot M, Peter E, Zerrer P, Kraemer F, Wiese S. Enhancing the lifetime prediction methodology for photovoltaic modules, Proceedings of $12^{\text {th }}$ Int. Conf. on Thermal, Mechanical and Multiphysics Simulation and Experimentsin Microelectronics and Microsystems, Linz, Austria, 2011; 1-4.

[3] Schmitt P, Kaiser P, Savio C, Tranitz M, Eitner U. Intermetallic Phase Growth and Reliability of Sn-Ag-Soldered Solar Cells, Energy Procedia, 2012; 27:664-669.

[4] Che FX, Pang JHL. Characterization of IMC layer and its effect on thermomechanical fatigue life of Sn-3.8Ag-0.7Cu solder joints, Journal of Alloys and Compounds, 2012; 541:6-13.

[5] Huan Y, Xue S, Zhang L, Ji F, Dei W. Reliability evaluation of CSP soldered joints based on FEM and Taguchi method, Computational Materials Science, 2010; 48:509512.

[6] Ladani LJ. Numerical analysis of thermo-mechanical reliability of through silicon vias (TSVs) and solder interconnects in 3-dimensional integrated circuits, Microelectronics Engineering, 2010; 87:208-215.

[7] Yang P, Tan G. Taguchi-numerical approach on thermo-mechanical reliability for PBGA, International Journal of Numerical Modelling: Electronic Networks, Devices and Fields, 2010; 24:437-447.

[8] Taguchi G. Quality Engineering (Taguchi Methods) For The Development of Electronic Circuit Technology, IEEE Transactions on Reliability, 1995; 44:225-229.

[9] Jeong J, Nochang P, Wonsik H, Changwoon H. Analysis for the Degradation Mechanism of Photovoltaic Ribbon Wire under Thermal Cycling, Proceedings of $37^{\text {th }}$ Photovoltaic Specialists Conference, Seattle, WA. USA, 2011; 003159-003161.

[10] Lechovič E, Erika H, Beáta S, Ingrid K, Koloman U. Solder Joint Reliability, <https://www.mtf.stuba.sk/docs/internetovy_casopis/2009/1/hodulova.pdf> (accessed March 12, 2013).

[11] McCluskey FP. Reliability Modeling for Photovoltaic Modules, Proceedings of Photovoltaic Module Reliability Workshop, Denver, Colorado, 2010. 
[12] Cuddalorepatta G, Abhijit D, Scott S, Jerome M, Todd T, James L. Durability of Pb- free solder between copper interconnect and silicon in photovoltaic cells, Progress in Photovoltaics: Research and Applications, 2010; 18(3):168-182.

[13] Wohlgemuth JH. Reliability of Photovoltaic Cells, Modules, Components, and Systems, Proceedings of SPIE conference, 7048, 2008.

[14] Klengel R, Härtel R, Schindler S, Schade D, Sykes B. Evaluation of the Mechanical Strength of Solar Cell Solder Joint Interconnects and Their Microstructural Properties by Developing a New Test and Inspection Equipment, 26th European Photovoltaic Solar Energy Conference and Exhibition, Hamburg, Germany, 2011; 1507-1511.

[15] Gierth P, Rebenklau L, Michaelis A. Evaluation of Soldering Processes for High Efficiency Solar Cells, 35th International Spring Seminar on Electronics Technology, Vienna, Austria, 2012; 133-137.

[16] Rogelj I, Ziger P, Eiselt P. PV Ribbon: Overview of Product Specifications and Comparison of Production Processes, SOLARCON, Shanghai, China, 2012.

[17] Webb JE, Hamilton JP. Physical Properties of Glass and the Requirements for Photovoltaic Modules, Proceedings of Photovoltaic Module Reliability Workshop, Golden, Colorado, USA, 2011; 1-18.

[18] Eitner U, Pander M, Kajari-Schröder S, Köntges M, Altenbach H. Thermomechanics of PV Modules Including the Viscoelasticity of Eva, Proceedings of 26th European Photovoltaic Solar Energy Conference and Exhibition, Hamburg, Germany, 2011; 32673269.

[19] Amalu EH, Ekere NN. High temperature reliability of lead-free solder joints in a flip chip assembly, Journal of Materials Processing Technology, 2012; 212:471-483.

[20] The Engineering Toolbox, <http://www.engineeringtoolbox.com/young-modulusd 417.html $>$ (accessed November $\left.6^{\text {th }}, 2015\right)$.

[21] Hopcroft MA, Nix WD, Kenny TW. What is the Young's Modulus of Silicon?, Journal of Microelectromechanical Systems, 2010; 19( 2):229-238.

[22] Wiese S, Kraemer F, Peter E, Seib J. Mechanical Problems of novel Back Contact Solar Modules, Proceedings of 13th International Conference on Thermal, Mechanical and Multi-Physics Simulation and Experiments in Microelectronics and Microsystems, EuroSimE, Cascais, near Lisbon, Portugal, 2012.

[23] Che FX, Pang JHL, Xiong BS, Xu L, Low TH. Lead Free Solder Joint Reliability Characterization for PBGA, PQFP AND TSSOP Assemblies, Proceedings of $55^{\text {th }}$ ECTC, Florida, USA, 2005; 916-921.

[24] Syed A. Accumulated Creep Strain and Energy Density Based Fatigue Life Prediction Models for SnAgCu Solder Joints, Proceedings of $54^{\text {th }}$ ECTC, Las Vegas, USA, 2004; 737-746.

[25] Pang JHL, Che FX. Isothermal Cyclic Bend Fatigue Test Method for Lead Free Solder Joints, Proceedings of $10^{\text {th }}$ Intersociety Conference on Thermal and Thermomechanical Phenomena in Electronics Systems, San Diego, California, USA, 2006; 1011-1017.

[26] Che FX, Pang JHL. Fatigue Reliability Analysis of Sn-Ag-Cu Solder Joints Subject to ThermalCycling, IEEE Transaction on Device and Materials Reliability, 2012; 13(1):3649.

[27] Jeong JS, Park N, Han C. Field Failure Mechanism Study of Solder Interconnection for Crystalline Silicon Photovoltaic Module, Microelectronics Reliability, 2012; 52:23262330.

[28] Montgomery DC. Design and Analysis of Experiments, John Wiley \& Sons, Inc.; 2013.

[29] Davies R, Coole T, Osypiw D. A Review of Traditional and Taguchi Design of Experiments: Devising a Method Selection Criteria, Proceedings of $25^{\text {th }}$ Flexible Automation and Intelligent Manufacturing, Wolverhampton, UK, 2015; 308-315. 
600

[30] Kumar S, Sarkar B. Design for Reliability with Weibull Analysis for Photovoltaic

601

602
Modules, International Journal of Current Engineering and Technology, 2013; 3(1):129134. 